\title{
Functional diversity of HIV-I envelope proteins expressed by contemporaneous plasma viruses
}

\author{
Tamara Nora, Francine Bouchonnet, Béatrice Labrosse, \\ Charlotte Charpentier, Fabrizio Mammano, François Clavel and
} Allan J Hance*

Address: Unité de Recherche Antivirale, INSERM U 552, Université Denis Diderot Paris 7, Paris F-75018, France

Email:Tamara Nora - nora@bichat.inserm.fr; Francine Bouchonnet - fbouchon@bichat.inserm.fr; Béatrice Labrosse - labrosse@bichat.inserm.fr; Charlotte Charpentier - charlotte.charpentier@egp.ap-hop-paris.fr; Fabrizio Mammano - mammano@pasteur.fr;

François Clavel - clavel@bichat.inserm.fr; Allan J Hance* - hance@bichat.inserm.fr

* Corresponding author

Published: 29 February 2008

Retrovirology 2008, 5:23 doi:10.1 186/1742-4690-5-23

This article is available from: http://www.retrovirology.com/content/5/I/23

(c) 2008 Nora et al; licensee BioMed Central Ltd.

This is an Open Access article distributed under the terms of the Creative Commons Attribution License (http://creativecommons.org/licenses/by/2.0), which permits unrestricted use, distribution, and reproduction in any medium, provided the original work is properly cited.

\begin{abstract}
Background: Numerous studies have shown that viral quasi-species with genetically diverse envelope proteins (Env) replicate simultaneously in patients infected with the human immunodeficiency virus type I (HIV-I). Less information is available concerning the extent that envelope sequence diversity translates into a diversity of phenotypic properties, including infectivity and resistance to entry inhibitors.
\end{abstract}

Methods: To study these questions, we isolated genetically distinct contemporaneous clonal viral populations from the plasma of 5 HIV-I infected individuals $(n=70)$, and evaluated the infectivity of recombinant viruses expressing Env proteins from the clonal viruses in several target cells. The sensitivity to entry inhibitors (enfuvirtide, TAK-799), soluble CD4 and monoclonal antibodies $(2 \mathrm{GI} 2,48 \mathrm{~d}, 2 \mathrm{F5})$ was also evaluated for a subset of the recombinant viruses $(\mathrm{n}=20)$.

Results: Even when comparisons were restricted to viruses with similar tropism, the infectivity for a given target cell of viruses carrying different Env proteins from the same patient varied over an approximately 10 -fold range, and differences in their relative ability to infect different target cells were also observed. Variable region haplotypes associated with high and low infectivity could be identified for one patient. In addition, clones carrying unique mutations in V3 often displayed low infectivity. No correlation was observed between viral infectivity and sensitivity to inhibition by any of the six entry inhibitors evaluated, indicating that these properties can be dissociated. Significant inter-patient differences, independent of infectivity, were observed for the sensitivity of Env proteins to several entry inhibitors and their ability to infect different target cells.

Conclusion: These findings demonstrate the marked functional heterogeneity of HIV-I Env proteins expressed by contemporaneous circulating viruses, and underscore the advantage of clonal analyses in characterizing the spectrum of functional properties of the genetically diverse viral populations present in a given patient. 


\section{Background}

The population of human immunodeficiency virus type 1 (HIV-1) present in a single infected patient at any given time can show remarkable diversity. Moreover, the extent of diversity can evolve over time and is different in different genes. The most striking changes in diversity occur in the envelope glycoproteins (Env). The initial transmission of HIV-1 can result in infection of the new host with multiple viruses expressing genetically diverse env sequences [1-6]. Early in the evolution of infection, however, viruses expressing extremely homeogeneous env sequences become dominant, presumably reflecting the selection of viruses that are best adapted for replication in available target cells, and/or resistant to the nascent host immune response [1-3,7]. This initial homogenization is followed by a period often lasting many years, in which both the diversity of the env sequences and the evolutionary distance from the initially dominant strain increase linearly by approximately $1 \%$ per year $[5,8-$ 17]. Subsequently, the extent of viral diversity begins to plateau and, in the late stages of disease, a decline in viral diversity can be observed $[8,11,12,18]$.

Although genetic diversity of the viral $e n v$ has been extensively studied, less information is available concerning the extent that these genetically diverse Env proteins also display functional diversity. Envelope sequences have been amplified from plasma or short-term cell cultures and used to produce recombinant or pseudotyped viruses expressing primary env sequences [19-25]. Most studies have found that only $40-70 \%$ of such viruses are infectious, but quantitative assessment of the replicative capacity of a large number of viruses expressing different envelope sequences from a single patient has not been reported.

It also remains unclear the extent to which other properties of the viral Env proteins are shared by coexisting quasi-species from a given patient. Viral isolates obtained from different individuals can differ in their sensitivity to inhibition by chemokines [26-30], entry inhibitors [31$37]$, certain monoclonal antibodies [32,38], and autologous serum $[26,39]$, but the extent that different viruses obtained from the same individual show similar sensitivity to a given entry inhibitor has not been extensively evaluated. Furthermore, replicative capacity, per se, can influence the sensitivity of viruses to inhibitors of entry $[26,31,36,40]$, but it remains unknown whether or not the sensitivity of viruses from a given patient to entry inhibitors correlates closely with replicative capacity.

We have recently described an approach that allows the direct isolation of contemporaneous clonal viruses from the plasma of infected individuals, including viruses capable of using CCR5 and/or CXCR4 viral coreceptors $[41,42]$. These viruses are potentially useful for the evaluation of the functional correlates of env genetic diversity.
First, each clonal virus emerges independently, and therefore viruses with low infectivity are not lost through competition with rapidly replicating viruses. Furthermore, the env sequences expressed by these viruses are genetically diverse, and the functional properties have not been modified by through mutation or recombination occurring during PCR. In this study, we have created recombinant viruses expressing Env proteins from these clonal viruses in a reporter construct expressing luciferase activity, and evaluated: i) the spectrum of infectivity observed for Env proteins expressed by contemporaneous viral clones from the same patient, ii) the ability of these viruses to infect different target cells, and, iii) the relationship between infectivity and the susceptibility of the Env proteins to several different entry inhibitors.

\section{Results \\ Diversity of envelope sequences}

Phylogenetic analysis indicated that env sequences (C1-V2 region) for all clones from each patient clustered together along with the consensus sequence obtained for bulk envelope sequences amplified directly from plasma by RT-PCR (Fig. 1). Viruses with both R5 and X4 tropism (see below)

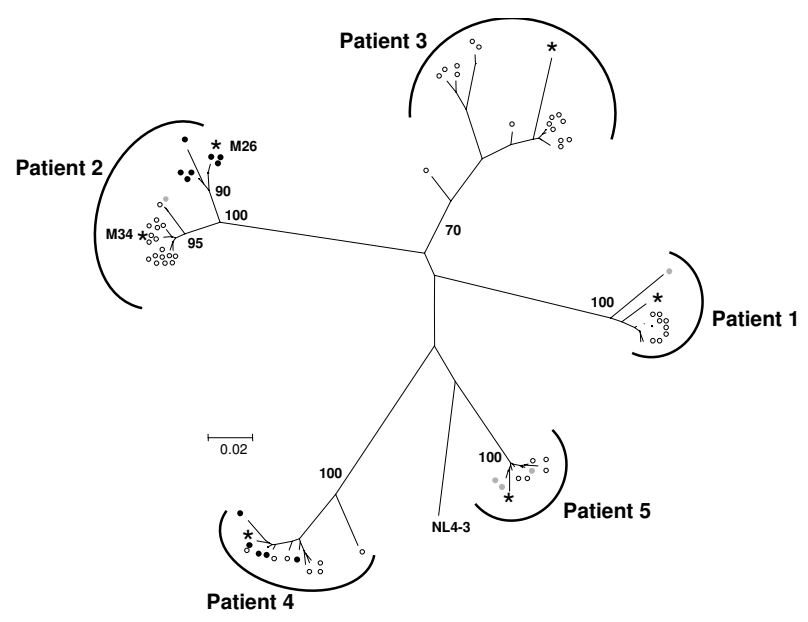

Figure I

Phylogenetic tree of envelope sequences of clonal viruses. Shown is the neighbor-joining phylogenetic tree for nucleotide sequences coding the region of env encompassing $\mathrm{Cl}$ to V2 (corresponding to nucleotides 6440 - 6809 of $\mathrm{HXB2}$ ) of the 70 clonal viruses evaluated in the study (open circles, strict R5 tropism, solid black circles, strict X4 tropism; solid gray circles, dual tropism), the consensus sequence of the same region for viral RNA amplified by RTPCR from an aliquot of the plasma sample used to generate the clonal viruses (stars), and the sequence of the laboratory strain pNL4-3. Bootstrap values are also indicated. For patient 2, the consensus sequence of plasma viruses grouped with clonal viruses with $\mathrm{X} 4$ tropism at $\mathrm{M} 26$, and with clonal viruses with $\mathrm{R} 5$ tropism at M34. 
were isolated from 4 patients. For patients 1 and 2, sequences for viruses with R5 tropism appeared to be phylogenetically distinct from those of viruses with $\mathrm{X} 4$ (patient 2) or dual (patient 1) tropism, and the sequence diversity among viruses with similar tropism was lower than that of the entire viral population. In contrast, for patients 4 and 5, envelope sequences in the V1-V2 region for viruses with R5 tropism were not segregated from those of viruses with X4 (patient 4) or dual (patient 5) tropism. For patient 2, the consensus env sequence for plasma viruses clustered with the sequences of viruses with $\mathrm{X} 4$ tropism at month 26 , but clustered with the sequences of viruses with R5 tropism at month 34 .

The nucleotide diversity of env sequences extending from $\mathrm{V} 1$ to the middle of $\mathrm{V} 4$, calculated by the method of Tajima-Nei, ranged from $0.018-0.060$, values typical of those obtained for sequences amplified from plasma by RT-PCR. The greatest diversity was observed for patient 3, despite that all viruses from this patient showed strict R5 tropism.

\section{Infectivity of recombinant viruses carrying primary envelope sequences in U373-R5 and U373-X4 target cells} To explore the functional capacities of Env proteins expressed by these clonal viruses, we generated recombinant reporter viruses in which the env sequence (gp120 + the extracellular domain of gp41) was derived from the different clonal viruses, and evaluated the ability of these luciferase-expressing viruses to infect U373 cells stably expressing CD4 and either CCR5 or CXCR4 co-receptors. All of the 70 recombinant viruses were infectious (Fig. 2). Viruses with strict $\mathrm{R} 5$ tropism were identified in all patients $(\mathrm{n}=53)$, but clones with R5X4 tropism $(\mathrm{n}=5)$ and/or strict $\mathrm{X} 4$ tropism $(\mathrm{n}=12)$ were also identified in 4 of the 5 patients studied. The infectivity of dual-tropic viruses tended to be similar in the U373-R5 and U373-X4 target cells (compare gray symbols in Figs. 2A and 2B). Without exception, the infectivity of clones with R5 tropism was at least 5-fold lower than the infectivity of recombinant viruses carrying the Env from the laboratory-adapted strain NL-AD8 [mean infectivity in U373-R5 cells: 22524 (RLU/ $\mathrm{sec}) /(\mathrm{ng} \mathrm{p} 24 / \mathrm{ml})]$. The infectivity of some clones with X4 tropism was equivalent to that observed for recombinant viruses carrying the Env from pNL4-3 [mean infectivity in U373-X4 cells: 2650 (RLU/sec)/(ng p24/ml)].

Considerable variability was observed in the infectivity of viruses carrying different $e n v$ sequences from the same patient. When U373-R5 cells were used as targets, the difference in infectivity between the most and least infectious viruses from each of the 5 patients averaged $1.0 \pm$ $0.26 \log _{10}$ (range $0.8-1.3 \log _{10}$ difference). Some interpatient variability in infectivity was also observed. When considered as a group, no significant differences in the infectivity of clones carrying Env proteins from patients

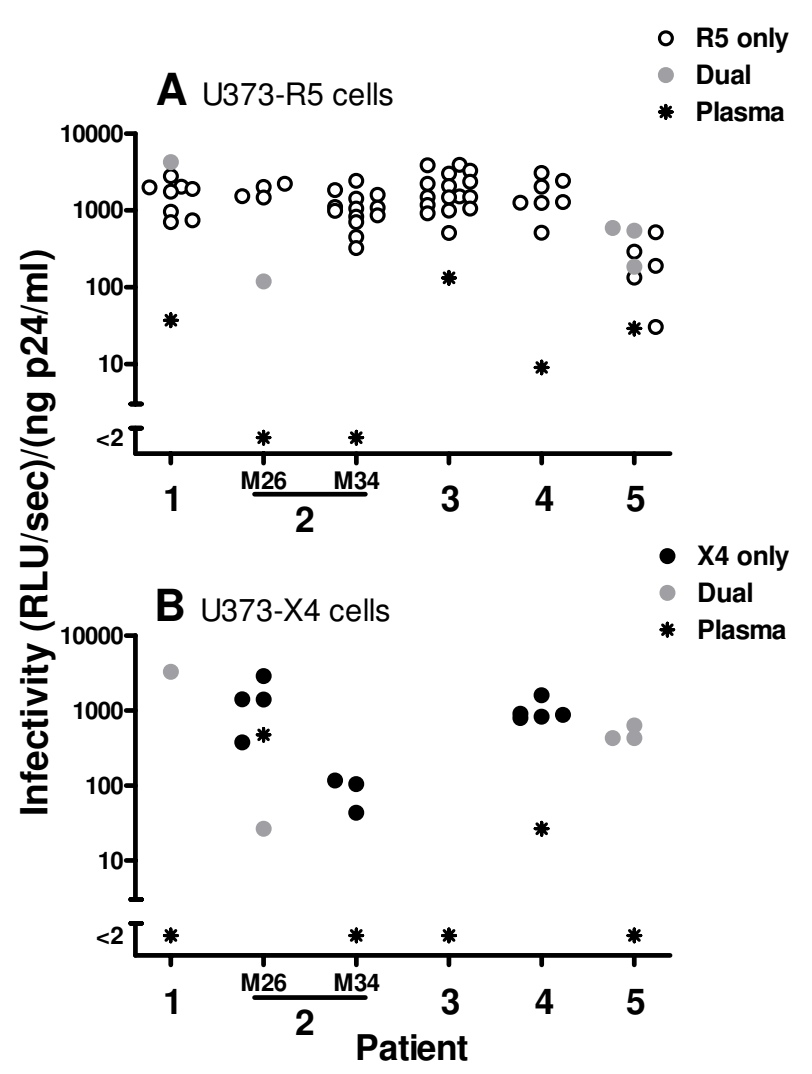

\section{Figure 2}

Infectivity and co-receptor usage of envelope proteins expressed by clonal viruses. Recombinant reporter viruses were generated in which the env sequence (gpl $20+$ the extracellular domain of $\mathrm{gp}^{4} \mathrm{I}$ ) was derived from clonal viruses isolated from plasma of patients chronically infected with HIV-I. The ability of these viruses, which express Renilla luciferase in the place of Nef, to infect U373 cells stably expressing CD4 and either CCR5 (panel A) or CXCR4 (panel B) co-receptors was measured by evaluating luciferase expression in target cells 44 hours after infection. For patient 2 , clonal viruses were obtained from plasma samples obtained 8 months apart (26 and 34 months after initial diagnosis). The ability of all recombinant viruses to infect the two cell types was evaluated, but results are shown only for viruses that induced significant luciferase activity in the indicated target cell type [>2 (RLU/sec) $/(\mathrm{ng}$ p $24 / \mathrm{ml})]$. Viruses could be classified as having strict R5 tropism (open symbols) strict X4 tropism (solid black symbols) and dual tropism (sold gray symbols). Results for viruses expressing env sequences amplified by RT-PCR from patient plasma is also shown (stars). Each symbol is the mean of at least 3 independent experiments; the mean coefficient of variation for these results is as follows: U373-R5 cells, $42 \%$ (range 3 $83 \%$ ); U373-X4 cells, $50 \%$ (range $10-78 \%$ ). For each patient, significant differences were found comparing the viruses with the highest and lowest infectivity ( $p<0.05-0.00$ l by t-test). 
1-4 were observed, but the infectivity of clones from each of these patients was significantly greater than that of clones from patient 5 ( $\mathrm{p}<0.05$ for all comparisons).

\section{Impact of the intracellular portion of gp4 I on viral infectivity}

The intracellular portion of gp41 is known to interact with Gag. To avoid potential incompatibilities between these viral proteins $[43,44]$, we initially evaluated the infectivity of recombinant viruses in which both the intracellular portion of gp41 and Gag were derived from the pNL4-3 viral strain. Changes in the intracellular domain of gp 41, however, have also been reported to influence Env function [4548], and it was important to evaluate the possibility that incompatibilities between the extracellular domains of Env in some of the viruses and the intracellular domain of gp41 from pNL4-3 contributed to the wide range of infectivities observed. To do so, we compared the infectivity of selected recombinant viruses in which the intracellular domain of gp41 was derived either from pNL4-3 or from the primary viral isolate. As shown in Fig. 3, the infectivities of the two

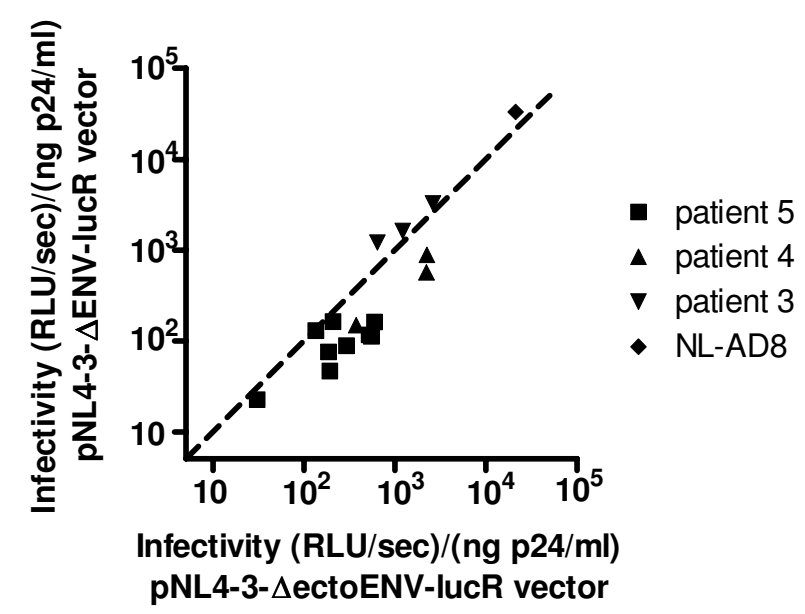

Figure 3

The effect of the origin of the intracellular portion of gp4 I on infectivity. For selected clonal viruses isolated from patient 3 (inverted triangles), patient 4 (triangles), patient 5 (squares) or from the laboratory-adapted strain NL-AD8 (diamond), two types of recombinant reporter viruses were generated, one in which gp $120+$ only the extracellular domain of gp4I was derived from the clonal virus ( $\mathrm{pNL} 4-3-\Delta$ ectoENVlucR, abscissa), and one in which gp 120 and all of gp4 I was derived from the clonal virus ( $\mathrm{PNL} 4-3-\Delta E N V$-lucR vector, ordinate). The ability of these viruses to infect U373-R5 cells was compared by evaluating luciferase expression in the target cells 44 hours after infection. The infectivity of each pair of viruses was evaluated in three independent experiments, and each symbol represents the mean of these determinations. The dotted line is the line of identity. The correlation coefficient (Spearman) for the data shown is $0.86(p<0.0001)$. constructs were strongly correlated (Spearman $\mathrm{r}=0.86$; $\mathrm{p}<$ $0.0001)$. Viruses that demonstrated relatively poor infectivity when the intracellular domain of gp41 was derived from pNL4-3 did not show improved infectivity when the homologous intracellular domain of gp41 was used (e.g., the viruses with Env from patient 5 and the least infectious virus from patient 4). Indeed, the use of the homologous intracellular domain of gp41 led to a moderate loss in infectivity for the viruses from patient 4 and some viruses from patient 5, consistent with the possibility that incompatibilities existed in these cases between the gp41 sequences and the gag protein from pNL4-3.

\section{Infectivity of recombinant viruses carrying primary envelope sequences in MT4-R5 cells}

For all 70 recombinant viruses, the amount of luciferase activity resulting from infection of $\mathrm{U} 373$ cells was greater than that seen after infection of MT4-R5 cells. For each patient, a significant correlation was observed between the infectivity of viruses with R5-exclusive tropism for U373-R5 and MT4-R5 target cells ( $\mathrm{p}<0.05$ for all comparisons). As was observed when U373 cells were used as targets, viruses carrying different env sequences from the same patient showed considerable variability in infectivity when MT4-R5 cells were infected (Fig. 4A). The difference in infectivity between the most and least infectious $\mathrm{R} 5$ viruses from each of the 5 patients averaged $1.2 \pm 0.31$ $\log _{10}$ (range $0.8-1.5 \log _{10}$ difference). As indicated above, the infectivity of viruses from patient 5 were strikingly lower than that of viruses from other patients when U373-R5 cells were used as targets. This difference was less striking when MT4-R5 cells were infected (compare Figs. 2A and 4A), although the infectivity of R5 viruses from patient 5 remained significantly lower than that of R5 viruses from patients 2 and 3 ( $\mathrm{p}<0.05$ for both comparisons).

Interestingly, considerable variability was observed when luciferase activity obtained following infection of the two cell types was expressed as a ratio (Fig. 4B). This ratio did not correlate with the infectivity of the viruses for U373 cells (Spearman $r=0.10, p=0.49$ ), but only viruses with relatively low infectivity for MT4-R5 cells [i.e., <110 (RLU/ $\mathrm{sec}) /(\mathrm{ng} \mathrm{p} 24 / \mathrm{ml})$ ] had values for this ratio that were greater than 20 (Fig. 5). The level of expression of both CD4 and CCR5 was approximately two-fold higher on U373-R5 cells than on MT4-R5 cells (Fig. 6). Thus, a possible explanation for these observations is that the infectivity of viruses for which a high ratio was observed are particularly sensitive to the levels of expression of CD4 and/or co-receptor, although other differences between U373-R5 cells and MT4-R5 cells may also influence the ability of viruses carrying different envelopes to infect these cell types. 


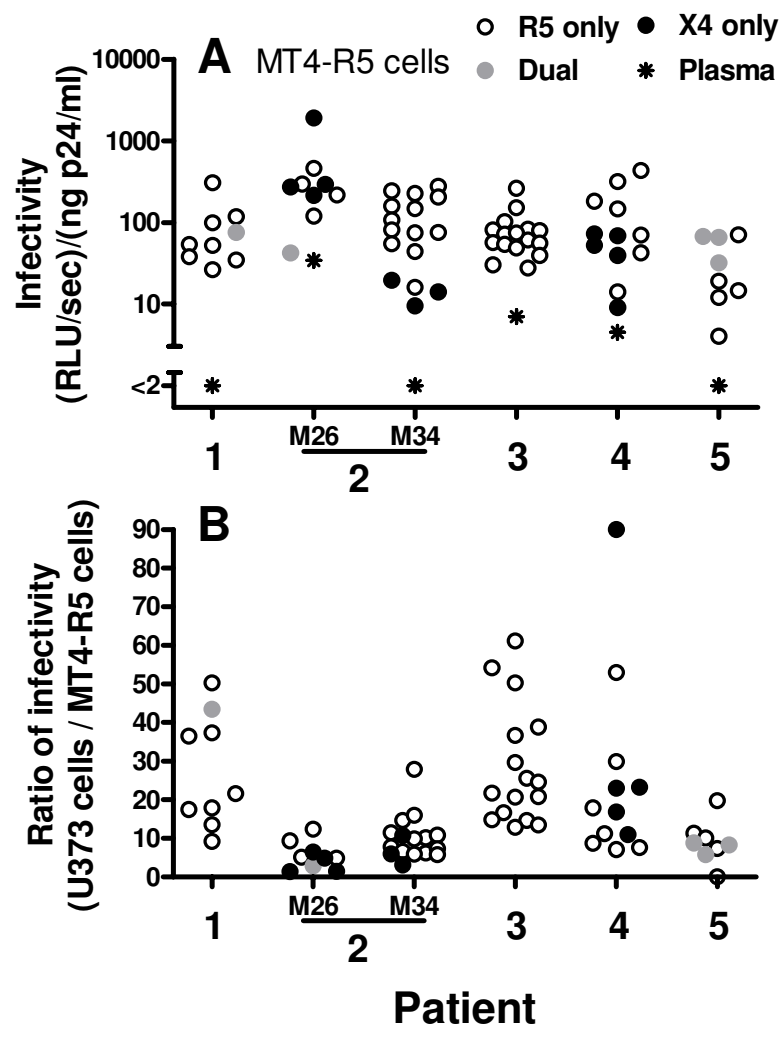

Figure 4

Infectivity of recombinant viruses carrying primary Env sequences in MT4-R5 cells. (A) Recombinant reporter viruses were generated as described in Fig. I legend, and the ability of these viruses to infect MT4-R5 cells was measured by evaluating luciferase expression in the target cells 44 hours after infection. For patient 2 , clonal viruses were obtained from plasma samples obtained 8 months apart (26 and 34 months after initial diagnosis). The tropism of the recombinant viruses, as defined by their ability to infect U373-R5 and U373-X4 cells is shown: strict R5, open symbols; dual, solid gray symbols; strict $X 4$, solid black symbols. Results for viruses expressing env sequences amplified by RTPCR from patient plasma is also shown (stars). Each symbol is the mean of at least 3 independent experiments; the mean coefficient of variation for these results is $37 \%$ (range I $78 \%$ ). For each patient, significant differences were found comparing the viruses with the highest and lowest infectivity ( $p<0.05-0.005$ by t-test). (B) For each recombinant virus, the infectivity [(RLU/sec)/(ng p 24/ml)] observed using U373 target cells and MT4-R5 target cells is expressed as a ratio.

It is noteworthy that the proportion of viruses with a relatively high infectivity ratio was different in different patients. The infectivity ratios of clones from patients 1,3 and 4 were significantly greater than that of patient 2 ( $\mathrm{p}<$ $0.001, \mathrm{p}<0.001$ and $\mathrm{p}<0.05$, respectively), and the infectivity ratio of clones from patient 3 was also significantly greater than that of patient $5(\mathrm{p}<0.05)$.

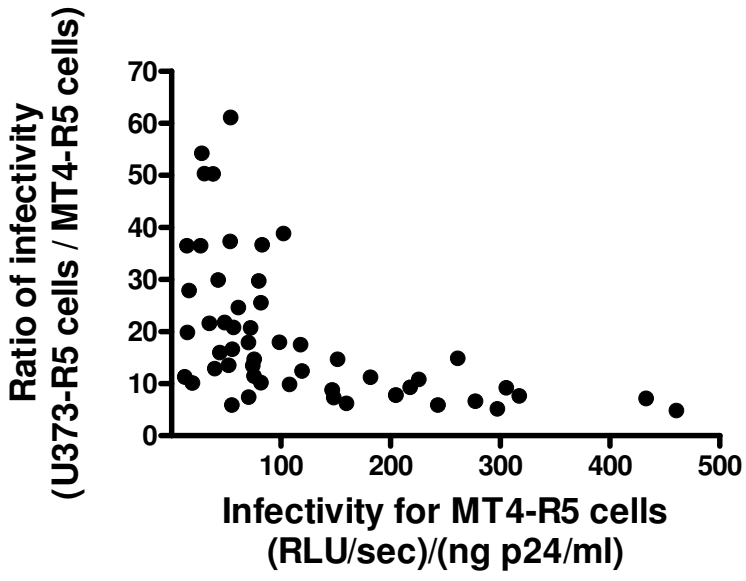

Figure 5

Relationship between the infectivity of recombinant viruses bearing envelope proteins from plasma viruses for MT4-R5 cells and U373-R5 cells. Recombinant reporter viruses were generated as described in Fig. I legend, and the ability of these viruses to infect MT4-R5 cells and U373-R5 cells was measured by evaluating luciferase expression in the target cells 44 hours after infection. For each of the 53 viruses with strict R5 tropism, the infectivity ratio (infectivity for U373-R5 cells/infectivity for MT4-R5 cells) is expressed as a function of the infectivity for MT4-R5 cells $[(\mathrm{RLU} / \mathrm{sec}) /(\mathrm{ng} \mathrm{P} 24 / \mathrm{ml})]$. A significant inverse correlation between these parameters was observed (Spearman $r=$ $-0.64, p<0.0001)$.

\section{Infectivity of recombinant viruses carrying envelope sequences amplified from plasma by RT-PCR}

In parallel with studies evaluating the infectivity of recombinant viruses carrying env sequences derived from clonal viruses, we evaluated the infectivity of recombinant viruses expressing env sequences amplified by RT-PCR from viral RNA extracted from the same plasma specimen from which the clonal viruses had been derived. The infectivity of viruses carrying plasma-derived env sequences for U373-R5 cells, although detectable in all cases except patient 2, was generally low, and was less than that of the clonal viruses from the same patient, usually by a substantial margin (Fig. 2A). The infectivity of viruses expressing plasma-derived env sequences for U373-X4 cells was detectable in only two samples (Fig. 2B). In both of these cases (patient 2, M26 and patient 4), clonal viruses with $\mathrm{X} 4$ exclusive tropism had been identified. The failure to detect infectivity of viruses carrying plasma-derived env sequences in other samples from which clonal viruses with strict $\mathrm{X} 4$ or dual tropism were identified may reflect the somewhat lower infectivity of the viruses with X4 tropism (e.g., patient 2, M34 and patient 5) and/or a lower proportion of viruses with $\mathrm{X} 4$ tropism in the sample (e.g., patient 1). As was observed for viruses carrying env 

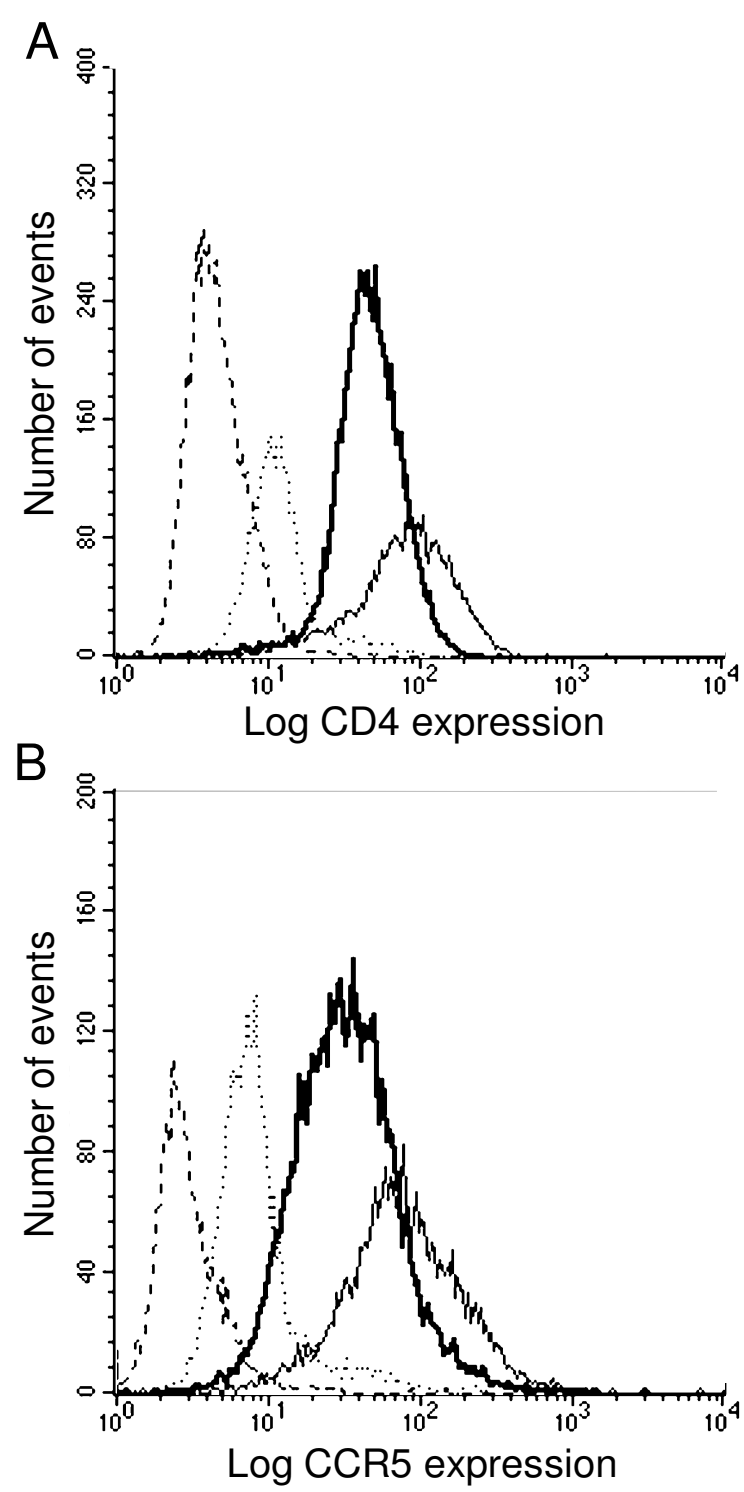

Figure 6

Expression of CD4 and CCR5 on U373-R5 cells and MT4-R5 cells. Cells were resuspended in PBS containing $20 \%$ human serum and incubated with directly-conjugated monoclonal antibodies or isotype-matched control antibodies conjugated with the same flurochrome. (A) CD4 expression on U373-R5 cells (thin solid line) and MT4-R5 cells (heavy solid line) detected using FITC-labelled mouse antihuman CD4 monoclonal antibody (clone RPA-T4). Binding of an isotype-matched control antibody conjugated with FITC is shown in the corresponding dashed lines. (B) CCR5 expression on U373-R5 cells (thin solid line) and MT4-R5 cells (heavy solid line) detected using phycoerythrin-conjugated mouse anti-human CCR5 monoclonal antibody (clone 2D7). Binding of an isotype-matched control antibody conjugated with phycoerythrin to these cells is shown in the corresponding dashed lines. sequences derived from clonal viruses, the infectivity of viruses carrying plasma-derived env sequences for MT4-R5 cells was usually reduced compared to that observed for U373 cells (Fig. 4A). Indeed, for patients 1 and 5, low level infectivity was detected toward U373-R5 cells, but infectivity was below detection when MT4-R5 cells were targeted.

\section{Sensitivity of recombinant viruses carrying primary envelope sequences to entry inhibitors}

Because the infectivity of clonal viruses carrying different env sequences from a given patient varied over a wide range, these viruses were useful in exploring the possible relationship between infectivity and sensitivity to inhibition by entry inhibitors. To do so, clonal viruses with R5tropism that exhibited a spectrum of infectivities towards U373-R5 cells and/or MT4-R5 cells were selected from 4 of the patients (Figs. 7A and 7B). For each of these 20 viruses, the IC50s were determined on U373-R5 target cells for two entry inhibitors (enfuvirtide and TAK-799), soluble $\mathrm{CD} 4$, and neutralizing monoclonal antibodies recognizing either gp120 (2G12,48d) or gp41 (2F5). No significant correlations were observed between the IC50s of these six inhibitors and the infectivity of the clonal viruses for either U373-R5 cells or MT4-R5 cells (data not shown, $\mathrm{p}>0.09$ for all Spearman correlations).

Viruses from different patients did, however, demonstrate differential sensitivity to these entry inhibitors, independent of infectivity (Fig. 7). Thus, significant differences in the median sensitivity to entry inhibitors by clonal viruses from different patients was observed by ANOVA for all entry inhibitors except TAK-799 ( $p$ values for KruskalWallis test: $p<0.001-0.05$ ), and for each of these inhibitors, significant differences in were also identified in pairwise comparisons of IC50s for viruses from different patients (Fig. 7).

\section{Genotype-phenotype correlations}

Nucleotide sequences for $e n v$ extending from the signal peptide to mid $\mathrm{C} 4$ region were available for all clones. The PSSM score developed by Jensen et al. [49] correctly distinguished all clones with R5-exclusive tropism and X4exclusive tropism, even though viruses from two of the patients were non-B subtypes. Three of the 6 Env proteins with dual tropism, however, were predicted to exhibit R5exclusive tropism (one clone each from patients 1, 2 and $5)$. The amino acid sequence of the $\mathrm{V} 3$ region of these dual-tropic clones from patients 1 and 2 differed at 6 and 1 positions, respectively, compared to that of the most similar R5-tropic Env identified in that patient, and these differences may explain the change in tropism. The V3 region of the misidentified dual-tropic envelope sequence from patient 5, however, was identical to that of other Env 

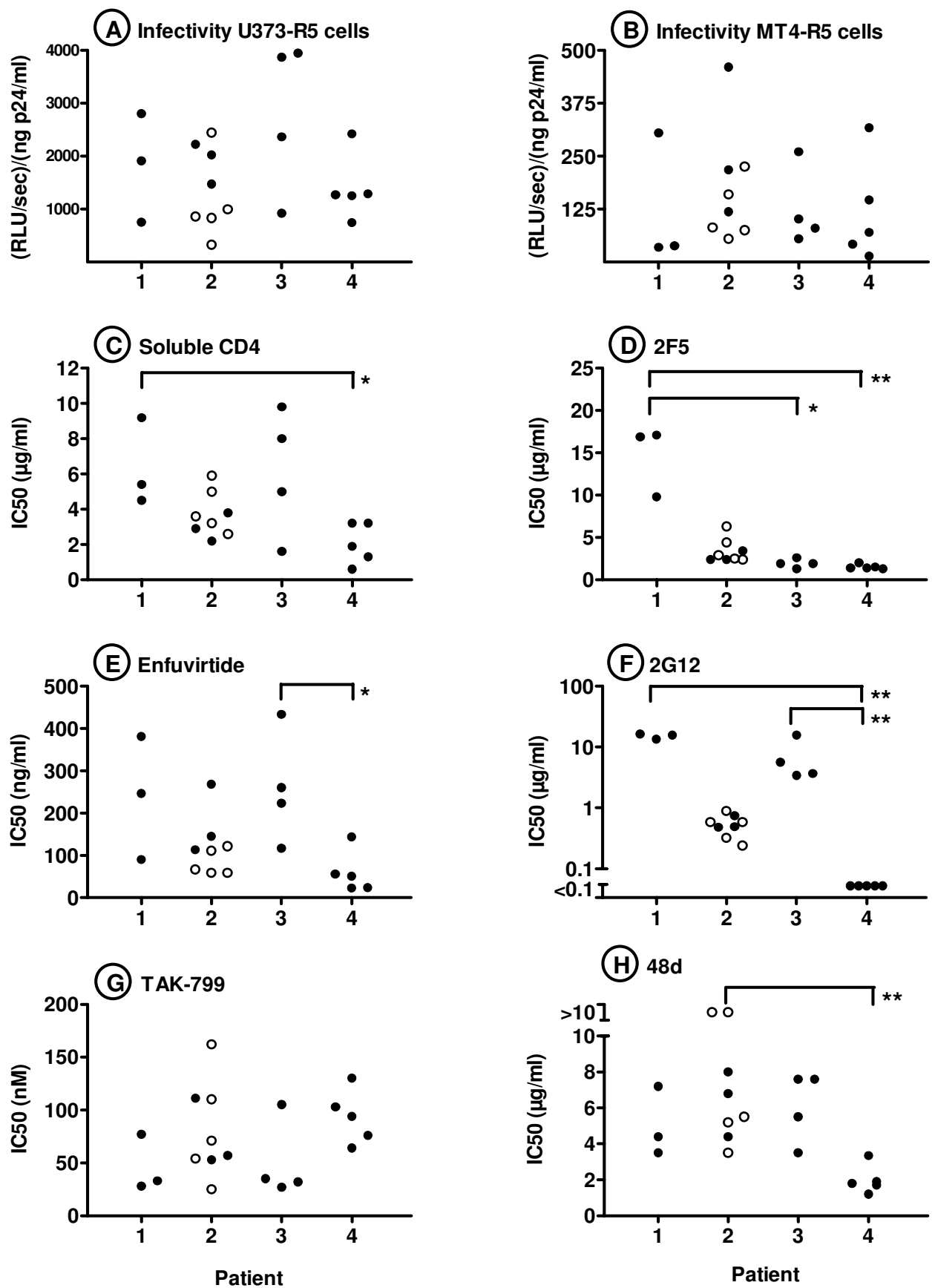

\section{Figure 7}

Sensitivity of recombinant viruses carrying primary envelope sequences to entry inhibitors. Clonal viruses with R5-tropism exhibiting a spectrum of infectivities towards U373-R5 cells (panel A) and/or MT4-R5 cells (panel B) were selected from among those obtained from patients I-4. For each of these 20 viruses, the IC50s were determined on U373-R5 cells for soluble CD4 (C), enfuvirtide (E), TAK-799 (G), and neutralizing monoclonal antibodies $2 F 5(D), 2$ I 2 (F), and 48d (H). Each symbol represents the mean of three independent determinations. For all inhibitors except TAK-799, significant patient-specific differences in IC50 were observed using the Kruskal-Wallis test. Brackets indicate significant pairwise differences in posttest comparisons performed using Dunn's multiple comparison test $(* p<0.05$; $* * p<0.01$ ). For patient 2 , clonal viruses were obtained from plasma samples obtained at both 26 months (solid symbols) and 34 months (open symbols) after initial diagnosis. 
with R5-exclusive tropism, indicating that sequences outside V3 influenced the tropism of this Env.

In general, viruses with strict R5-tropism from the same individual expressed a relatively small number of haplotypes within a given variable $(\mathrm{V})$ region. For example, the number of distinct haplotypes identified for the V3 region ranged from 1 (patient 1) to 4 (patient 2). Significant differences in the infectivity of R5-tropic viruses as a function of haplotype were observed for the variable regions 2 and 3 (V2 and V3) of patient 2 ( $p<0.02$ and $\mathrm{p}<0.03$ respectively using the Kruskal-Wallis test). As shown in Fig. 8, the viruses from this patient expressing V3 region haplotypes 2 and 3 were significantly less infectious than those expressing haplotype 1 ( $p<0.01$ using the Mann-Whitney test), and viruses expressing the V2 region haplotype 4 were less infectious than those expressing the V2 region haplotypes $1-3(p<0.001)$. Most of the viruses expressing the V2 haplotype associated with low infectivity (haplotype 4) also expressed V3 haplotypes associated with low infectivity. However, one of the viruses expressed this V2 haplotype in association with the V3 haplotype 1, which was usually associated with good infectivity (red arrow in Fig. 8A). The infectivity of this virus was, nevertheless, low (red arrow in Fig. 8B), suggesting that expression of the V2 haplotype 4 was a major determinant for low infectivity in this patient. It is noteworthy that clones from patient 2 expressing the V2 haplotype 4 were obtained only from the plasma sample obtained at month 34 , and 9/13 clones with R5-tropism isolated at this time point expressed this V2 haplotype.

No significant associations between infectivity and haplotype were observed for the variable regions expressed by the other patients, and no association between infectivity and the haplotypes in the constant regions were identified. One factor that could confound such analyses is the presence of deleterious mutations elsewhere in the envelope sequence. In this regard, we found that four of the 53 viruses with strict R5 tropism had V3 sequences containing a single amino acid polymorphism not seen in any other sequence from that patient. The recombinant viruses carrying 3 of these unique V3 polymorphisms had the lowest infectivity for U373-R5 cells of any virus evaluated from that sample.

\section{Discussion}

In this study we have explored the functional properties of Env proteins from contemporaneous HIV-1 biological clones isolated from the plasma of chronically infected patients. Even when comparisons were restricted to viruses with similar tropism, these genetically diverse Env proteins were found to exhibit striking functional diversity, including, i) a wide range of infectivities for a given target cell, ii) differences in relative ability to infect differ- ent target cells, and iii) differences in sensitivity to certain entry inhibitors. In addition to the functional diversity observed among viruses from a single patient, significant inter-patient differences were also observed for some characteristics of Env proteins, including sensitivity to several different entry inhibitors and the relative ability of viruses to infect different target cells. Interestingly, no correlation was observed between viral infectivity and sensitivity to entry inhibitors, indicating that these properties are, to some extent, dissociable. These findings demonstrate the marked functional heterogeneity of HIV-1 Env proteins expressed by contemporaneous circulating viruses, and underscore the advantage of clonal analyses in characterizing such viral populations.

The observation that Env proteins expressed by contemporaneous viruses display a broad spectrum of infectivity towards a given target cell raises the question of the forces responsible for this functional diversity. One factor that can drive the development of diversity is the selection in a single patient of numerous viral subpopulations with distinct Env functional properties. Genetically distinct viral populations replicating in different tissues or cellular compartments have been identified in numerous studies [50-54]. Such populations can also result in functional diversity, as illustrated by the obvious example of the coexistence of viruses with different tropism. Indeed, we found that the coexistence of viruses with $\mathrm{R} 5$ and $\mathrm{X} 4$ tropism could make an important contribution to overall genetic diversity in patients from whom both populations were isolated.

The high mutation and recombination rates of HIV-1 are also likely to have an important impact on infectivity. Because of the numerous structural constraints in viral proteins, including Env, many mutations will prove to be deleterious for fitness. Similarly, recombination events that shuffle env segments can modify the function of Env proteins $[55,56]$. Indeed, genetic evidence supports the idea that purifying selection against deleterious mutations is occurring in the env region [57]. In this regard, we observed that 3 of 4 viruses in which V3 sequences contained a single amino acid polymorphism not seen in any other sequence from that patient had low infectivity. The association of such rare polymorphisms with poor infectivity is consistent with the possibility that the deleterious mutations contribute to the wide spectrum infectivity observed in these studies, although further studies are required to directly demonstrate the impact of such specific genetic differences on viral infectivity.

The extent that genetic differences deleterious for viral replication accumulate because they are associated with escape from immune responses is also an important issue. In this regard, we observed that a V2 haplotype associated 

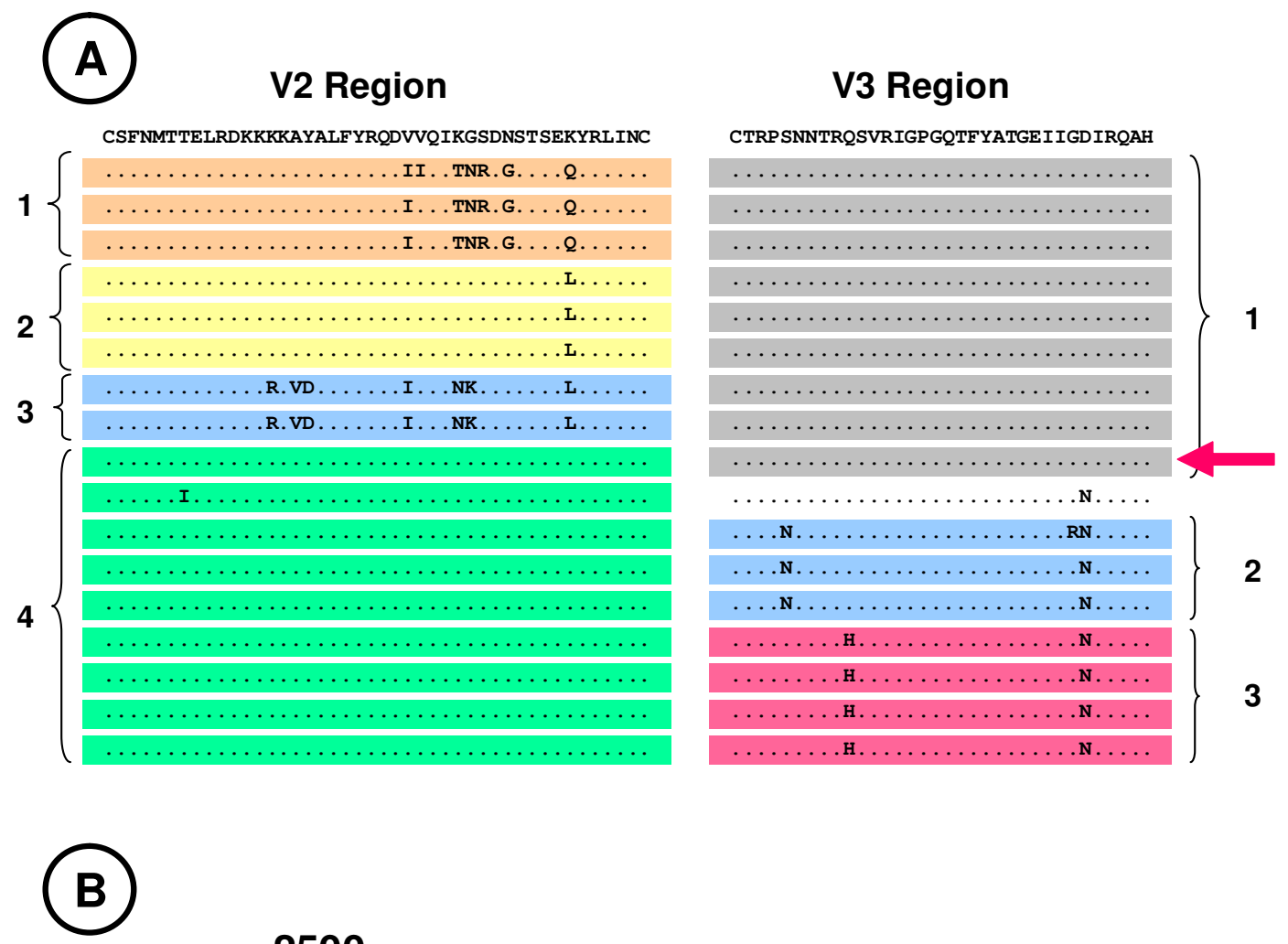

\section{Figure 8}

Expression of $\mathbf{V} 2$ and $\mathbf{V} 3$ region haplotypes in Env proteins of clonal viruses from patient 2 and viral infectivity. (A) The haplotypes in the V2 region (left) and V3 region (right) of the Env proteins expressed by the 17 clonal viruses from patient 2 with strict R5 tropism are shown. The consensus amino sequence is shown on the top line, and only amio acids differing from the consensus sequence are shown for each clone. For each variable region, sequences that are identical or that differ by a single amino acid substitution not identified in another sequence are highlighted by the same color, and these haplotypes are also identifed by numbers adjacent to the brackets. The red arrow indicates the envelope expressing the V2 region haplotype 4 associated with the $\mathrm{V} 3$ region haplotype I (see text). (B) The infectivity of recombinant viruses expressing these Env proteins using U373-R5 cells is shown. For each of the variable regions, the color of the symbols corresponds to that of the $\mathrm{V}$ region haplotype expressed by that virus. The red arrow indicates the infectivity of the clone expressing the $\mathrm{V} 2$ region haplotype 4 associated with the $\mathrm{V} 3$ region haplotype I. 
with reduced viral infectivity emerged in patient 2 over an 8 month interval, and had become the dominant haplotype. This haplotype differed by a single amino acid change from another haplotype observed in this individual (Fig. 8). Such a modification would be typical of escape from neutralizing antibodies or cytotoxic T-cells targeting this epitope, although other explanations are also possible (e.g., adaptation of the Env proteins to improve the targeting of a specific cell type or fixation of a deleterious mutation through stochastic processes). Further studies comparing the spectrum of infectivity of Env proteins present in the genetically homogeneous viral populations of viruses present immediately before seroconversion with that observed following the development of the anti-viral immune response will help define the extent that selection of variants associated with immune escape affects Env function.

The possibility that viral evolution during in vitro culture contributed to diversity should also be considered. For example, greatest viral diversity was observed for patient 3 , and clones from this patient emerged later than those from the other patients. However, control experiments (see Materials and Methods) showed no evidence for viral evolution during culture. In particular, the absence of polymorphic bases in the sequences of the viral clones indicates that variants were not emerging to the extent that they were detectable by bulk sequencing, and therefore were not sufficiently abundant to influence either viral diversity or the assessment of infectivity.

The spectrum of Env infectivity in vivo is almost certainly greater than observed in our study. The Env proteins studied by us were derived from viruses capable of productively infecting MT4-R5 cells. We must assume that the env sequences of these viruses were enriched for those with high infectivity in this cell system, and Env proteins carrying lethal mutations or mutations preventing efficient propagation in MT4-R5 cell cultures would not be sampled. We found that recombinant viruses produced using bulk env sequences amplified directly from plasma by RTPCR had an infectivity that was lower than that of recombinant viruses carrying Env proteins from the clonal viruses derived from the same sample, as would be expected if a significant proportion of viruses present in plasma carry Env proteins that are noninfectious or whose infectivity is too low to permit emergence of clones during in vitro culture. The finding in previous studies that a substantial portion of viruses expressing env sequences amplified from plasma by RT-PCR show low or undetectable infectivity is also compatible with this interpretation [19$23,53,58]$. It should be emphasized, however, that additional artifacts may also contribute to the low infectivity observed in our study for viruses carrying bulk env sequences amplified from plasma by RT-PCR, such that the infectivity of the recombinant viruses would not be reflective of viruses in plasma. First, recombinant viruses formed using mixtures of sequences amplified from plasma will express heterotrimeric Env proteins, including, for some samples, trimers containing sequences with both $\mathrm{X} 4$ and $\mathrm{R} 5$ tropism. In this regard, our preliminary results suggest that the infectivity of viruses generated using mixtures of clonal env sequences may be lower than the mean infectivity of viruses expressing each of these env sequences as homotrimers. In addition, during the amplification of env sequences from plasma, recombination between the heterogeneous target sequences can occur, and may form sequences in which incompatibilities between Env segments are deleterious to infectivity. In view of these uncertainties, further studies will be required to fully define the spectrum of infectivity of Env proteins expressed by viruses in plasma.

An interesting observation from our study was the absence of correlation between the infectivity of the recombinant viruses studied and their susceptibility to several different entry inhibitors or neutralizing antibodies. The affinity of Env-coreceptor interactions is one factor that can influence both Env fusion kinetics and the sensitivity of Env to the inhibition by enfuvirtide and TAK-779 [35,36,56,59], although mutations that modify sensitivity to co-receptor antagonists without modifying fusion kinetics have also been described $[36,60]$. The failure to find a correlation between Env infectivity and sensitivity to these inhibitors suggests that differences affecting membrane fusion that are independent of Envcoreceptor affinity (e.g., "fusogenicity") or differences affecting other Env properties (e.g., the expression or stability of Env trimers) make an important contribution to the wide spectrum of Env infectivities observed in this study.

We did observe, however, that sensitivity to inhibition by soluble CD4, enfuvirtide, and three different neutralizing antibodies were properties that were shared by viruses from a given patient, independent of their infectivity. Similarly, Ray et al. found differences in enfuvirtide sensitivity comparing Env clones isolated from different patients [58]. These findings suggest that genetic determinants important in defining the sensitivity to these entry inhibitors lie in regions that are not necessarily subject to extensive diversity. For example, determinants in the relatively well conserved membrane proximal ectodomain of gp41 appear to be important in determining sensitivity to both enfuvirtide and the monoclonal antibody $2 \mathrm{~F} 5[61,62]$. Determinants of sensitivity to inhibitors of coreceptor binding appear to be subject to greater intra-patient variability. No patient-specific differences in sensitivity to TAK779 was observed in our study, and considerable variability in sensitivity of individual Env clones from a given 
patient has been reported for several other coreceptor antagonists [58]. Thus, the impact of viral diversity on sensitivity to entry inhibitors is likely to differ for inhibitors with different modes of action. Our findings suggest, however, that resistance to entry inhibitors is not likely to be a useful surrogate marker for viral infectivity.

\section{Conclusion}

These studies highlight the difficulty in defining the replicative "fitness" of viral Env proteins from a given patient, because viruses can display a large spectrum of Env infectivities and this spectrum is different in different cell types. Similarly, our studies confirm that considerable variability can be encountered in the sensitivity of individual Env proteins to entry inhibitors, and that this parameter can vary independently of Env infectivity. Only through clonal analysis can the heterogeneity of these Env properties be fully appreciated. As discussed above, further characterization of the spectrum of Env infectivity at different stages of disease evolution should provide insights into factors that govern viral pathogenesis. Because these parameters may differ in different individuals, this information may prove to be of prognostic significance.

\section{Methods \\ Patients}

Clonal viral populations were obtained from five patients chronically infected with HIV-1. Clinical information of these patients is summarized in Table 1. All patients were evaluated at the Hôpital Bichat - Claude Bernard, and informed consent was obtained prior to participation in the study. Three of the patients were not receiving treatment with antiretroviral drugs at the time of initial evaluation (patients 1-3). Patient 1 had never been treated. Patient 2 had received intermittent treatment with several regimens containing nucleoside analog reverse transcriptase (RT) inhibitors and protease inhibitors over a two year period, but had discontinued therapy 2 months before evaluation. Patient 3 had been treated for 1 year with AZT+3TC+efavirenz, but treatment had been discontinued for 3 years prior to evaluation. Patients 4 and 5 had $\mathrm{a} \geq 2$ year history of treatment failure. Both had been treated initially with nucleoside analog RT inhibitors, and subsequently received regimens also including non-nucleoside RT inhibitors, protease inhibitors and/or enfuvirtide in various combinations, but plasma virus had never become undetectable. Neither patient had received antiviral agents that target viral entry for at least 1 year prior to evaluation. For patient 2, clonal viral populations were obtained from two different plasma samples obtained eight months apart.

\section{Clonal viral populations}

Clonal viral populations were obtained as previously described [41,42]. Briefly, MT4-R5 cells, expressing CCR5 and CXCR4 receptors, were resuspended at $2 \times 10^{6}$ cells/ $\mathrm{ml}$ in complete medium containing $1 \%(\mathrm{v} / \mathrm{v}) \mathrm{DMSO}$, and $0.25 \mathrm{ml}$ aliquots were distributed in 24-well plates. An equal volume of plasma, diluted in complete medium containing (final concentration) 1\% DMSO and $2 \mu \mathrm{g} / \mathrm{ml}$ DEAE-dextran, was added to each well. The plates were centrifuged ( $860 \mathrm{xg}$; 2 hours; $\left.22^{\circ} \mathrm{C}\right)$, and cultured for 4 hours at $37^{\circ} \mathrm{C}$ to permit viral entry. Cells were recovered, washed once, and $200 \mu \mathrm{l}$ aliquots containing $2 \times 10^{4}$ cells were distributed into 96-well plates. The cultures were maintained at $37^{\circ} \mathrm{C}$ in $5 \% \mathrm{CO}_{2}$, and were passaged with a 1:10 dilution every 7 days. Cultures were inspected by light microscopy, and when patent cytopathic changes were observed, the culture supernatant and the cell pellet from infected wells were recovered separately and frozen at $-80^{\circ} \mathrm{C}$. If viral replication was observed in $>20 \%$ of the wells, the experiment was repeated after further dilution of the plasma. The days in culture at which the clones from different patients emerged is shown in Table 1. Seventy-five percent of all clones had emerged by day 24 .

Findings in this and our prior studies [41,42] supported the conclusion that viral evolution was not occurring during culture. In control experiments, pNL4-3-derived viruses containing protease mutations that substantially impaired viral fitness (replicative capacity $10-20 \%$ of wild-type virus) were used in our protocol to generate

Table I: Clinical characteristics of patients at time of study and number of clonal viruses obtained

\begin{tabular}{|c|c|c|c|c|c|c|c|}
\hline Patient & Age/Sex & $\begin{array}{c}\text { Months since } \\
\text { diagnosis }\end{array}$ & Treatment* & $\begin{array}{l}\text { Viral Load } \\
\left(\log _{10}\right)\end{array}$ & $\begin{array}{l}\text { CD4 T-cells } \\
\text { (cells/ } \mu \mathrm{l})\end{array}$ & $\begin{array}{l}\text { Number of } \\
\text { clones }\end{array}$ & $\begin{array}{l}\text { Time to } \\
\text { emergence of } \\
\text { clones (days) }\end{array}$ \\
\hline 1 & $35 / M$ & 17 & none & 5.52 & 276 & 9 & $18-26$ \\
\hline \multirow[t]{2}{*}{2} & $38 / M$ & 26 & none & 6.67 & 7 & 9 & $11-20$ \\
\hline & & 34 & 3TC ddI LPV \# & 6.32 & 18 & 16 & $\mid I-20$ \\
\hline 3 & $4 I / M$ & 210 & none & 6.22 & $15 \mid$ & 16 & $20-36$ \\
\hline 4 & $38 / M$ & 114 & 3TC SQV/RTV & 5.43 & 11 & 12 & $14-27$ \\
\hline 5 & $40 / M$ & 139 & $\begin{array}{l}\text { 3TC ddl TDF } \\
\text { TPV/RTV APV }\end{array}$ & 5.33 & 8 & 8 & $10-2 \mid$ \\
\hline
\end{tabular}

*Abbreviations for antiretroviral drugs are as follows: amprenavir (APV), didanosine (ddl), lamivudine (3TC), ritonavir (RTV), saquinavir (SQV), tenofovir (TDF), tipranavir (TPV). \#Poor compliance suspected. 
clonal viruses, and the protease region from 36 different clones was sequenced. Without exception, these sequences were identical to the original plasmid $(14,256$ bases) and no evidence of reversion of the deleterious mutations was observed, despite that reversion of any of the mutations would have substantially improved fitness. In addition, proviral DNA (including env) was amplified and sequenced for every clone used in our study, and without exception, no ambiguous bases were identified. The absence of detectable polymorphisms is consistent with the interpretation that variants were not emerging during culture to the extent that their presence was detectable by bulk sequencing (i.e., $>10 \%$ ).

\section{Vectors}

We have previously described a pNL4-3-derived proviral vector in which the env sequence coding for most of gp120 and the ectodomain of gp41 (nucleotides 6480 to 8263 ) has been deleted and replaced by a linker sequence containing a unique MluI restriction site [34]. To create a similar vector expressing Renilla luciferase in place of Nef, the BamHI - NcoI fragment was removed, and the remaining fragment was ligated with the BamHI - KpnI fragment from pTN7-NL [63] and the KpnI - NcoI fragment from pNL4-3, creating (pNL4-3- $\triangle$ ectoENV-lucR). An analogous proviral vector was also constructed in which all of the env sequence except for that coding the 13 N-terminal amino acids of gp120 and the 29 C-terminal amino acids of gp41 (nucleotides 6344-8691) has been deleted and replaced by a linker sequence containing a unique NheI restriction site (pNL4-3- $\Delta$ ENV-lucR).

\section{Amplification of proviral DNA}

DNA was extracted from the infected cell pellets using a QIAamp Viral DNA mini kit (Qiagen, Valencia, CA), resuspended in $100 \mu \mathrm{l}$ of $10 \mathrm{mM}$ Tris buffer containing 1 mM EDTA, and used as a template to amplify env fragments. To amplify the $2.2 \mathrm{~kb}$ fragment that spans the env region deleted from the pNL4-3- $\Delta$ ectoENV-lucR vector and also containing $147 \mathrm{bp}(\mathrm{N}$-terminal) and $258 \mathrm{bp}$ (Cterminal) extensions to allow homologous recombination with this vector, reactions $(50 \mu \mathrm{l})$ contained $2 \mu \mathrm{l}$ DNA, $200 \mu \mathrm{M}$ each dNTPs, $1.5 \mathrm{mM} \mathrm{Mg}^{2+}, 0.5 \mu \mathrm{M}$ each oligonucleotides E5 (5'-GTCTATTATGGGGTACCTGTGTGGA) and FuB (5'-GGTGGTAGCTGAAGAGGCACAGG), $1 \mathrm{U}$ Phusion hot start DNA polymerase (Finnzymes, Espoo, Finland), and $1 \mathrm{X}$ Phusion HF reaction buffer. Cycling conditions were as follows: $98^{\circ} \mathrm{C}$ for $30 \mathrm{sec}$, followed by 5 cycles at $98^{\circ} \mathrm{C}$ for $5 \mathrm{sec}, 72^{\circ} \mathrm{C}$ for $5 \mathrm{sec}$ and $72^{\circ} \mathrm{C}$ for $90 \mathrm{sec}$ each; 5 cycles at $98^{\circ} \mathrm{C}$ for $5 \mathrm{sec}, 70^{\circ} \mathrm{C}$ for $5 \mathrm{sec}$ and $72^{\circ} \mathrm{C}$ for $90 \mathrm{sec}$ each; 30 cycles at $98^{\circ} \mathrm{C}$ for $5 \mathrm{sec}$, $68^{\circ} \mathrm{C}$ for $20 \mathrm{sec}$ and $72^{\circ} \mathrm{C}$ for 90 sec each; with a final step at $72^{\circ} \mathrm{C}$ for $10 \mathrm{~min}$. PCR products were purified by QIAquick PCR Purification Kit (Qiagen). Aliquots of the purified DNA was electrophoresed into agarose gels and stained with ethidium bromide to verifiy that a single band of appropriate size had been amplified and to permit quantification of the product. The $2.6 \mathrm{~kb}$ fragment that spans the env region deleted from the pNL4-3- $\triangle \mathrm{ENV}$ lucR vector and also comprises $143 \mathrm{bp}(\mathrm{N}$-terminal) and $104 \mathrm{bp}$ (C-terminal) extensions to allow homologous recombination with this vector was amplified using similar conditions, except that oligonucleotides EB1 (5'GAAAGAGCAGAAGACAGTGGCAATGA) and EB2 (5'ACTTGCCACCCATCTTATAGCAAA) were used, and cycling conditions were: $98^{\circ} \mathrm{C}$ for $30 \mathrm{sec}$, followed by 40 cycles at $98^{\circ} \mathrm{C}$ for $5 \mathrm{sec}, 70^{\circ} \mathrm{C}$ for $20 \mathrm{sec}$ and $72^{\circ} \mathrm{C}$ for 90 sec each; and a final step at $72^{\circ} \mathrm{C}$ for $10 \mathrm{~min}$.

To amplify env sequences present in plasma, RNA was isolated from plasma using a QIAamp RNA Blood Mini Kit (Qiagen), and cDNA was synthesized using SuperScript III reverse transcriptase (Invitrogen, Carlsbad, CA) and random hexamer primers. Env sequences were amplified in a single reaction using the protocol described above.

\section{Cell culture}

293T cells and U373-CD4 cells were cultured in Dulbecco's modified Eagle medium supplemented with $10 \%$ fetal calf serum, $100 \mathrm{U} / \mathrm{ml}$ penicillin G and $100 \mu \mathrm{g} / \mathrm{ml}$ streptomycin (complete medium). MT4-R5 cells were cultured in similarly supplemented RPMI-1640 medium. For U373-CD4 cells stably expressing CCR5 or CXCR4 [64], medium also contained $10 \mu \mathrm{g} / \mathrm{ml}$ puromycin and $100 \mu \mathrm{g} /$ $\mathrm{ml}$ hygromycin $\mathrm{B}$.

\section{Production of recombinant viruses}

The techniques used to produce recombinant viruses have previously been described $[34,65,66]$. Briefly, 293 T cells that had been grown to $80 \%$ confluency in T25 flasks were co-transfected with $8 \mu \mathrm{g}$ of MluI-linearized pNL4-3- $\Delta$ ectoENV-lucR vector (or NheI-linearized pNL4-3- $\Delta$ ENVlucR vector) and $1 \mu \mathrm{g}$ of the corresponding PCR product using the calcium phosphate precipitation method, and cultured in $3 \mathrm{ml}$ of complete medium. After $18 \mathrm{~h}$, cells were washed with phosphate-buffered saline (PBS) and culture medium was replaced. Forty-four h after transfection culture medium was recovered and centrifuged (800 $\mathrm{xg}$; $10 \mathrm{~min}$ ), and p24 antigen present in the supernatant was measured using an enzyme-linked immunosorbent assay (Innotest HIV antigen mAB, Innogenetics, Gent, Belgium).

\section{Evaluation of viral infectivity}

The infectivity of recombinant viruses for different target cell types was determined by measuring luciferase activity. To do so, target cells were plated in black-wall, clear bottom 96-well plates (Greiner, Courtaboeuf, France). U373 cells were plated at $2 \times 10^{3}$ cells/well $48 \mathrm{~h}$ prior to infection; MT4-R5 cells were plated at $5 \times 10^{4}$ cells/well on the 
day of infection. Medium was removed and replaced with $60 \mu \mathrm{l}$ of complete medium containing serial two-fold dilutions of freshly harvested supernatants from transfected cells containing 0.069 - 50 ng p24/ml. Forty-four hours after infection, $20 \mu \mathrm{l}$ of $4 \mathrm{X}$ luciferase lysis buffer (Renilla luciferase assay system, Promega, Charbonnières, France) was added to each well, and plates were maintained at room temperature for $30 \mathrm{~min}$. Wells were sequentially injected with $100 \mu \mathrm{l}$ of luciferase substrate (Promega), and 3 seconds later, light emission (relative light units, RLU) was measured over a two sec interval using a Microlumat LB96P luminometer (Berthold, Oak Ridge, TN). Each sample was evaluated in triplicate. RLU were plotted as a function of amount of p24 used to infect the cells, and infectivity was defined as the slope [(RLU/ $\mathrm{sec}) /(\mathrm{ng} \mathrm{p} 24 / \mathrm{ml})$ ] as determined by linear regression; in this analysis, each replicate RLU value was treated as an individual point.

In preliminary experiments, we compared the infectivity of viruses obtained after transfection of $293 \mathrm{~T}$ cells with proviral plasmids, and viruses created by recombination between env sequences amplified from the same plasmid and the pNL4-3-derived $\Delta$ Env vector according to our protocol. The infectivity of the viruses produced through recombination was $89 \pm 37 \%$ (mean $\pm S D ; n=5)$ of that observed for viruses obtained directly by transfection ( $\mathrm{p}>$ 0.2 by paired t-test).

For each viral Env protein studied, infectivity was determined for each cell type in at least three independent experiments. Infection was considered undetectable if the RLU observed for the highest concentration of p24 evaluated was less than $500 \mathrm{RLU} / \mathrm{sec}$ (i.e., infectivity <2 (RLU/ $\mathrm{sec}) /(\mathrm{ng} \mathrm{p} 24 / \mathrm{ml})$. The mean coefficient of variation for clonal Env proteins with detectable infectivity was as follows: U373-R5 cells $(n=58), 42 \%$; U373-X4 cells $(n=$ 17), 50\%; MT4-R5 cells $(\mathrm{n}=70), 37 \%$.

\section{Inhibition of infectivity by entry inhibitors}

To measure the susceptibility of recombinant viruses to inhibition by enfuvirtide and TAK-799, U373-R5 cells were plated at a density of $6 \times 10^{3}$ cells/well as described above, and infected with the same dose of recombinant virus in the absence or the presence of increasing concentrations of enfuvirtide (1.6 to 5,000 ng/ml; T20, American Peptide Company, Sunnyvale, CA) or TAK-799 (0.8 to 2500 nM; NIH AIDS Research and Reference Reagent Program). Forty four hours after infection, luciferase activity was measured as described above. For each virus, an amount of p 24 was used that gave approximately $5 \times 10^{4}$ RLU/second for cells infected in the absence of inhibitor. Each experimental condition was evaluated in triplicate. To determine the concentration of inhibitor required for reduce viral infectivity by 50\% (IC50), data was fitted to a sigmoid dose-response curve with variable slope.

The susceptibility of recombinant viruses to inhibition by soluble CD4 (R\&D Systems, Minneapolis, MN) and monoclonal antibodies 48d (human anti-gp120, NIH AIDS Research and Reference Reagent Program), 2G12 (human anti-gp120, Polymun Scientific, Vienna, Austria) and 2F5 (human anti-gp41, Polymun Scientific) was measured by similar techniques, except that recombinant viruses were preincubated for $1 \mathrm{~h}$ at $37^{\circ} \mathrm{C}$ with serial three-fold dilutions of soluble $\mathrm{CD} 4$ or monoclonal antibodies, before using $60 \mu \mathrm{l}$ of the mixture to infect target cells. For each viral Env, infectivity was determined for each inhibitor cell type in at least two, and usually three independent experiments. The mean coefficient of variation for the six entry inhibitors ranged from $25 \%$ (enfuvirtide) to $64 \%$ (soluble CD4).

\section{Cytofluorometry}

U373 cells were detached by incubation in PBS containing $0.8 \%$ EDTA. Cells were resuspended in PBS containing $20 \%$ human serum $\left(1 \times 10^{6}\right.$ cells; $\left.100 \mu \mathrm{l}\right)$ and $10 \mu \mathrm{l}$ of one of the following monoclonal antibodies: phycoerythrinconjugated mouse anti-human CCR5 (clone 2D7), phycoerythrin-conjugated mouse anti-human CXCR4 (clone 12G5), FITC-conjugated mouse anti-human CD4 (clone RPA-T4), or similarly conjugated isotype-matched control antibodies (BD Biosciences, San Jose, CA). Following a 1 $\mathrm{h}$ incubation at $4^{\circ} \mathrm{C}$, cells were washed once and analyzed using a FACSCalibur flow cytometer (BD Biosciences). Analysis was restricted to viable cells, identified on the basis of forward and $90^{\circ}$ scatter.

\section{Data analysis}

Results are expressed as mean \pm SD unless otherwise indicated. Comparisons between groups were performed using the Kruskal-Wallis test. Post test comparisons, performed only if $\mathrm{p}<0.05$, were made using Dunn's multiple comparison test. Correlations were evaluated using the Spearman test. Nucleotide diversity was determined using the method of Tajima and Nei [67].

\section{Competing interests}

The author(s) declare that they have no competing interests.

\section{Authors' contributions}

$\mathrm{TN}, \mathrm{FB}$ performed the experiments and contributed to the analysis of data and writing the manuscript. BL, FM designed and constructed the vectors used and participated in design of the studies. CC contributed to obtaining the viral clones and the genetic studies. FC, $\mathrm{AJH}$ participated in the design of the study, the analysis of data 
and wrote the manuscript. All authors read and approved the final manuscript.

\section{Acknowledgements}

This work was supported in part by grants from the Agence Nationale de Recherches sur le SIDA (ANRS, 2005/002) and from Sidaction. The following reagent was obtained through the AIDS Research and Reference Reagent Program, Division of AIDS, NIAID, NIH: monoclonal antibody 48d from Dr. James E. Robinson; TAK-799 with permission of Takeda Chemical Industries, Ltd.

\section{References}

I. Zhang LQ, MacKenzie P, Cleland A, Holmes EC, Brown AJ, Simmonds $P$ : Selection for specific sequences in the external envelope protein of human immunodeficiency virus type I upon primary infection. J Virol 1993, 67:3345-3356.

2. Learn GH, Muthui D, Brodie SJ, Zhu T, Diem K, Mullins Jl, Corey L: Virus population homogenization following acute human immunodeficiency virus type I infection. J Virol 2002, 76:11953-11959.

3. Poss M, Rodrigo AG, Gosink |l, Learn GH, de Vange Panteleeff D, Martin HL Jr., Bwayo J, Kreiss JK, Overbaugh J: Evolution of envelope sequences from the genital tract and peripheral blood of women infected with clade A human immunodeficiency virus type I. J Virol 1998, 72:8240-825I.

4. Verhofstede C, Demecheleer E, De Cabooter N, Gaillard P, Mwanyumba F, Claeys P, Chohan V, Mandaliya K, Temmerman M, Plum J: Diversity of the human immunodeficiency virus type I (HIVI) env sequence after vertical transmission in mother-child pairs infected with HIV-I subtype A. J Virol 2003, 77:3050-3057.

5. Ritola K, Pilcher CD, Fiscus SA, Hoffman NG, Nelson JA, Kitrinos $\mathrm{KM}$, Hicks CB, Eron JJ Jr., Swanstrom R: Multiple VI/V2 env variants are frequently present during primary infection with human immunodeficiency virus type I. J Virol 2004, 78: | |208-|| $2 \mid 8$.

6. Sagar M, Kirkegaard E, Long EM, Celum C, Buchbinder S, Daar ES, Overbaugh J: Human immunodeficiency virus type I (HIV-I) diversity at time of infection is not restricted to certain risk groups or specific HIV-I subtypes. J Virol 2004, 78:7279-7283.

7. Delwart E, Magierowska M, Royz M. Foley B, Peddada L, Smith R, Heldebrant C, Conrad A, Busch M: Homogeneous quasispecies in 16 out of 17 individuals during very early HIV-I primary infection. Aids 2002, 16:189-195.

8. Delwart EL, Pan H, Sheppard HW, Wolpert D, Neumann AU, Korber $B$, Mullins Jl: Slower evolution of human immunodeficiency virus type I quasispecies during progression to AIDS. J Virol 1997, 71:7498-7508.

9. Liu SL, Schacker T, Musey L, Shriner D, McElrath MJ, Corey L, Mullins Jl: Divergent patterns of progression to AIDS after infection from the same source: human immunodeficiency virus type I evolution and antiviral responses. J Virol 1997, 71:4284-4295.

10. Lukashov VV, Kuiken CL, Goudsmit J: Intrahost human immunodeficiency virus type I evolution is related to length of the immunocompetent period. I Virol 1995, 69:69| I-6916.

II. McDonald RA, Mayers DL, Chung RC, Wagner KF, Ratto-Kim S, Birx DL, Michael NL: Evolution of human immunodeficiency virus type I env sequence variation in patients with diverse rates of disease progression and T-cell function. J Virol 1997, 71:187I-1879.

12. Nowak MA, Anderson RM, McLean AR, Wolfs TF, Goudsmit J, May RM: Antigenic diversity thresholds and the development of AIDS. Science |99|, 254:963-969.

13. Shankarappa R, Margolick JB, Gange SJ, Rodrigo AG, Upchurch D, Farzadegan H, Gupta P, Rinaldo CR, Learn GH, He X, Huang XL, Mullins $\mathrm{Jl}$ : Consistent viral evolutionary changes associated with the progression of human immunodeficiency virus type I infection. J Virol 1999, 73:10489-10502

14. Wolfs TF, de Jong JJ, Van den Berg H, Tijnagel JM, Krone WJ, Goudsmit J: Evolution of sequences encoding the principal neutralization epitope of human immunodeficiency virus $I$ is host dependent, rapid, and continuous. Proc Natl Acad Sci U SA 1990, 87:9938-9942.
15. Wolinsky SM, Korber BT, Neumann AU, Daniels M, Kunstman KJ, Whetsell AJ, Furtado MR, Cao Y, Ho DD, Safrit JT: Adaptive evolution of human immunodeficiency virus-type I during the natural course of infection. Science 1996, 272:537-542.

16. Zhang L, Diaz RS, Ho DD, Mosley JW, Busch MP, Mayer A: Hostspecific driving force in human immunodeficiency virus type I evolution in vivo. J Virol 1997, 71:2555-256 |

17. Markham RB, Wang WC, Weisstein AE, Wang Z, Munoz A, Templeton A, Margolick J, Vlahov D, Quinn T, Farzadegan H, Yu XF: Patterns of HIV-I evolution in individuals with differing rates of CD4 T cell decline. Proc Natl Acad Sci U S A 1998, 95: I 2568-I 2573.

18. Riddle TM, Shire NJ, Sherman MS, Franco KF, Sheppard HW, Nelson JA: Sequential turnover of human immunodeficiency virus type I env throughout the course of infection. J Virol 2006, 80: $10591-10599$.

19. Pierson T, Hoffman TL, Blankson J, Finzi D, Chadwick K, Margolick JB, Buck C, Siliciano JD, Doms RW, Siliciano RF: Characterization of chemokine receptor utilization of viruses in the latent reservoir for human immunodeficiency virus type I. J Virol 2000, 74:7824-7833.

20. Ohagen A, Devitt A, Kunstman KJ, Gorry PR, Rose PP, Korber B, Taylor J, Levy R, Murphy RL, Wolinsky SM, Gabuzda D: Genetic and functional analysis of full-length human immunodeficiency virus type I env genes derived from brain and blood of patients with AIDS. J Virol 2003, 77: 12336-12345.

2I. Gao F, Morrison SG, Robertson DL, Thornton CL, Craig S, Karlsson G, Sodroski J, Morgado M, Galvao-Castro B, von Briesen H, Beddows S, Weber J, Sharp PM, Shaw GM, Hahn BH: Molecular cloning and analysis of functional envelope genes from human immunodeficiency virus type I sequence subtypes $A$ through $G$. The WHO and NIAID Networks for HIV Isolation and Characterization. J Virol 1996, 70:165I-1667.

22. Zhang PF, Chen X, Fu DW, Margolick JB, Quinnan GV Jr.: Primary virus envelope cross-reactivity of the broadening neutralizing antibody response during early chronic human immunodeficiency virus type I infection. J Virol I999, 73:5225-5230.

23. Cham F, Zhang PF, Heyndrickx L, Bouma $P$, Zhong $P$, Katinger $H$, Robinson J, van der Groen G, Quinnan GV Jr.: Neutralization and infectivity characteristics of envelope glycoproteins from human immunodeficiency virus type $I$ infected donors whose sera exhibit broadly cross-reactive neutralizing activity. Virology 2006, 347:36-5I.

24. Li M, Gao F, Mascola JR, Stamatatos L, Polonis VR, Koutsoukos M, Voss G, Goepfert P, Gilbert P, Greene KM, Bilska M, Kothe DL, Salazar-Gonzalez JF, Wei X, Decker JM, Hahn BH, Montefiori DC: Human immunodeficiency virus type $I$ env clones from acute and early subtype $B$ infections for standardized assessments of vaccine-elicited neutralizing antibodies. J Virol 2005, 79: $10108-10125$.

25. Skrabal K, Saragosti S, Labernardiere JL, Barin F, Clavel F, Mammano F: Human immunodeficiency virus type I variants isolated from single plasma samples display a wide spectrum of neutralization sensitivity. J Virol 2005, 79: I | 848-I I 857.

26. Trkola A, Kuster H, Leemann C, Ruprecht C, Joos B, Telenti A, Hirschel B, Weber R, Bonhoeffer S, Gunthard HF: Human immunodeficiency virus type I fitness is a determining factor in viral rebound and set point in chronic infection. J Virol 2003, 77:13146-13155.

27. Jansson M, Backstrom E, Bjorndal A, Holmberg V, Rossi P, Fenyo EM, Popovic M, Albert J, Wigzell H: Coreceptor usage and RANTES sensitivity of non-syncytium-inducing HIV-I isolates obtained from patients with AIDS. J Hum Virol 1999, 2:325-338.

28. Koning FA, Kwa D, Boeser-Nunnink B, Dekker J, Vingerhoed J, Hiemstra $H$, Schuitemaker $H$ : Decreasing sensitivity to RANTES (regulated on activation, normally $T$ cell-expressed and secreted) neutralization of CC chemokine receptor 5-using, non-syncytium-inducing virus variants in the course of human immunodeficiency virus type $I$ infection. J Infect Dis 2003, 188:864-872.

29. Karlsson I, Antonsson L, Shi Y, Oberg M, Karlsson A, Albert J, Olde B, Owman C, Jansson M, Fenyo EM: Coevolution of RANTES sensitivity and mode of CCR5 receptor use by human immunodeficiency virus type I of the R5 phenotype. J Virol 2004, 78: $11807-11815$.

30. Torre VS, Marozsan AJ, Albright JL, Collins KR, Hartley O, Offord RE, Quinones-Mateu ME, Arts EJ: Variable sensitivity of CCR5-tropic 
human immunodeficiency virus type I isolates to inhibition by RANTES analogs. J Virol 2000, 74:4868-4876.

31. Repits J, Oberg M, Esbjornsson J, Medstrand P, Karlsson A, Albert J, Fenyo EM, Jansson M: Selection of human immunodeficiency virus type I R5 variants with augmented replicative capacity and reduced sensitivity to entry inhibitors during severe immunodeficiency. J Gen Virol 2005, 86:2859-2869.

32. Stalmeijer EH, Van Rij RP, Boeser-Nunnink B, Visser JA, Naarding MA, Schols $D$, Schuitemaker $H$ : In vivo evolution of $X 4$ human immunodeficiency virus type I variants in the natural course of infection coincides with decreasing sensitivity to CXCR4 antagonists. / Virol 2004, 78:2722-2728.

33. Koning FA, Koevoets C, van der Vorst TJ, Schuitemaker H: Sensitivity of primary R5 HTV-I to inhibition by RANTES correlates with sensitivity to small-molecule R5 inhibitors. Antivir Ther 2005, 10:231-237.

34. Labrosse B, Labernardiere JL, Dam E, Trouplin V, Skrabal K, Clavel F, Mammano F: Baseline susceptibility of primary human immunodeficiency virus type I to entry inhibitors. I Virol 2003, 77:1610-1613

35. Reeves JD, Gallo SA, Ahmad N, Miamidian JL, Harvey PE, Sharron M, Pohlmann S, Sfakianos JN, Derdeyn CA, Blumenthal R, Hunter E, Doms RW: Sensitivity of HIV-I to entry inhibitors correlates with envelope/coreceptor affinity, receptor density, and fusion kinetics. Proc Natl Acad Sci U S A 2002, 99:16249-16254.

36. Reeves JD, Miamidian JL, Biscone MJ, Lee FH, Ahmad N, Pierson TC, Doms RW: Impact of mutations in the coreceptor binding site on human immunodeficiency virus type I fusion, infection, and entry inhibitor sensitivity. J Virol 2004, 78:5476-5485

37. Safarian D, Carnec X, Tsamis F, Kajumo F, Dragic T: An anti-CCR5 monoclonal antibody and small molecule CCR5 antagonists synergize by inhibiting different stages of human immunodeficiency virus type I entry. Virology 2006, 352:477-484.

38. Rusert P, Kuster H, Joos B, Misselwitz B, Gujer C, Leemann C, Fischer M, Stiegler G, Katinger H, Olson WC, Weber R, Aceto L, Gunthard $\mathrm{HF}$, Trkola A: Virus isolates during acute and chronic human immunodeficiency virus type I infection show distinct patterns of sensitivity to entry inhibitors. J Virol 2005, 79:8454-8469.

39. Joos B, Trkola A, Fischer M, Kuster H, Rusert P, Leemann C, Boni J, Oxenius A, Price DA, Phillips RE, Wong JK, Hirschel B, Weber R, Gunthard HF: Low human immunodeficiency virus envelope diversity correlates with low in vitro replication capacity and predicts spontaneous control of plasma viremia after treatment interruptions. I Virol 2005, 79:9026-9037.

40. Sullivan N, Sun Y, Li J, Hofmann W, Sodroski J: Replicative function and neutralization sensitivity of envelope glycoproteins from primary and T-cell line-passaged human immunodeficiency virus type I isolates. J Virol I 995, 69:44I3-4422.

41. Charpentier C, Nora T, Tenaillon O, Clavel F, Hance A): Extensive recombination among human immunodeficiency virus type I quasispecies makes an important contribution to viral diversity in individual patients. J Virol 2006, 80:2472-2482.

42. Nora T, Charpentier C, Tenaillon O, Hoede C, Clavel F, Hance AJ: Contribution of recombination to the evolution of human immunodeficiency viruses expressing resistance to antiretroviral treatment. J Virol 2007, 81:7620-7628.

43. Murakami T, Freed EO: Genetic evidence for an interaction between human immunodeficiency virus type I matrix and alpha-helix 2 of the gp4I cytoplasmic tail. J Virol 2000, 74:3548-3554

44. West JT, Weldon SK, Wyss S, Lin X, Yu Q, Thali M, Hunter E: Mutation of the dominant endocytosis motif in human immunodeficiency virus type I gp4l can complement matrix mutations without increasing Env incorporation. J Virol 2002, 76:3338-3349.

45. Davis MR, Jiang J, Zhou J, Freed EO, Aiken C: $\mathbf{A}$ mutation in the human immunodeficiency virus type I Gag protein destabilizes the interaction of the envelope protein subunits gp I 20 and gp4I. J Virol 2006, 80:2405-24I7.

46. Edwards TG, Wyss S, Reeves JD, Zolla-Pazner S, Hoxie JA, Doms RW, Baribaud F: Truncation of the cytoplasmic domain induces exposure of conserved regions in the ectodomain of human immunodeficiency virus type I envelope protein. I Virol 2002, 76:2683-2691.
47. Gabuzda DH, Lever A, Terwilliger E, Sodroski J: Effects of deletions in the cytoplasmic domain on biological functions of human immunodeficiency virus type I envelope glycoproteins. J Virol 1992, 66:3306-3315.

48. Lambele M, Labrosse B, Roch E, Moreau A, Verrier B, Barin F, Roingeard P, Mammano F, Brand D: Impact of natural polymorphism within the gp4 I cytoplasmic tail of human immunodeficiency virus type $I$ on the intracellular distribution of envelope glycoproteins and viral assembly. J Virol 2007, $81: 125-140$.

49. Jensen MA, Li FS, van 't Wout $A B$, Nickle DC, Shriner D, He HX, McLaughlin S, Shankarappa R, Margolick JB, Mullins Jl: Improved coreceptor usage prediction and genotypic monitoring of R5-to-X4 transition by motif analysis of human immunodeficiency virus type I env V3 loop sequences. J Virol 2003, 77:13376-13388

50. Fulcher JA, Hwangbo Y, Zioni R, Nickle D, Lin X, Heath L, Mullins JI, Corey L, Zhu T: Compartmentalization of human immunodeficiency virus type I between blood monocytes and CD4+ T cells during infection. J Virol 2004, 78:7883-7893.

5I. Sullivan ST, Mandava U, Evans-Strickfaden T, Lennox JL, Ellerbrock TV, Hart CE: Diversity, divergence, and evolution of cell-free human immunodeficiency virus type $I$ in vaginal secretions and blood of chronically infected women: associations with immune status. J Virol 2005, 79:9799-9809.

52. Pillai SK, Good B, Pond SK, Wong JK, Strain MC, Richman DD, Smith DM: Semen-specific genetic characteristics of human immunodeficiency virus type I env. J Virol 2005, 79: I734-I742.

53. Peters PJ, Bhattacharya J, Hibbitts S, Dittmar MT, Simmons G, Bell J, Simmonds P, Clapham PR: Biological analysis of human immunodeficiency virus type I R5 envelopes amplified from brain and lymph node tissues of AIDS patients with neuropathology reveals two distinct tropism phenotypes and identifies envelopes in the brain that confer an enhanced tropism and fusigenicity for macrophages. J Virol 2004, 78:6915-6926.

54. Ghaffari G, Tuttle DL, Briggs D, Burkhardt BR, Bhatt D, Andiman WA, Sleasman JW, Goodenow MM: Complex determinants in human immunodeficiency virus type I envelope gp I 20 mediate CXCR4-dependent infection of macrophages. J Virol 2005, 79:|3250-|326|.

55. Poumbourios P, Maerz AL, Drummer HE: Functional evolution of the HIV-I envelope glycoprotein I 20 association site of glycoprotein 4I. J Biol Chem 2003, 278:42I49-42I60.

56. Derdeyn CA, Decker JM, Sfakianos JN, Zhang Z, O'Brien WA, Ratner L, Shaw GM, Hunter E: Sensitivity of human immunodeficiency virus type I to fusion inhibitors targeted to the gp4I first heptad repeat involves distinct regions of gp $4 I$ and is consistently modulated by gp I 20 interactions with the coreceptor. J Virol 200I, 75:8605-86|4

57. Edwards CT, Holmes EC, Pybus OG, Wilson DJ, Viscidi RP, Abrams EJ, Phillips RE, Drummond AJ: Evolution of the human immunodeficiency virus envelope gene is dominated by purifying selection. Genetics 2006, 174: I44I-I453.

58. Ray N, Harrison JE, Blackburn LA, Martin JN, Deeks SG, Doms RW: Clinical resistance to enfuvirtide does not affect susceptibility of human immunodeficiency virus type $I$ to other classes of entry inhibitors. J Virol 2007, 81:3240-3250.

59. Lobritz MA, Marozsan AJ, Troyer RM, Arts EJ: Natural variation in the $v 3$ crown of human immunodeficiency virus type I affects replicative fitness and entry inhibitor sensitivity. J Virol 2007, $81: 8258-8269$.

60. Biscone MJ, Miamidian JL, Muchiri JM, Baik SS, Lee FH, Doms RW, Reeves JD: Functional impact of HIV coreceptor-binding site mutations. Virology 2006, 35 I:226-236.

6I. Heil ML, Decker JM, Sfakianos JN, Shaw GM, Hunter E, Derdeyn CA: Determinants of human immunodeficiency virus type I baseline susceptibility to the fusion inhibitors enfuvirtide and T-649 reside outside the peptide interaction site. J Virol 2004, 78:7582-7589.

62. Muster T, Steindl F, Purtscher M, Trkola A, Klima A, Himmler G, Ruker $F$, Katinger $\mathrm{H}$ : A conserved neutralizing epitope on gp4I of human immunodeficiency virus type I. J Virol 1993 , 67:6642-6647.

63. Neumann T, Hagmann I, Lohrengel S, Heil ML, Derdeyn CA, Krausslich HG, Dittmar MT: T20-insensitive HIV-I from naive patients 
exhibits high viral fitness in a novel dual-color competition assay on primary cells. Virology 2005, 333:25I-262.

64. Labrosse B, Brelot A, Heveker N, Sol N, Schols D, De Clercq E, Alizon M: Determinants for sensitivity of human immunodeficiency virus coreceptor CXCR4 to the bicyclam AMD3 I 00. J Virol 1998, 72:638I-6388.

65. Skrabal K, Trouplin V, Labrosse B, Obry V, Damond F, Hance AJ, Clavel $F$, Mammano F: Impact of antiretroviral treatment on the tropism of HIV-I plasma virus populations. Aids 2003, 17:809-8|4.

66. Trouplin V, Salvatori F, Cappello F, Obry V, Brelot A, Heveker N, Alizon M, Scarlatti G, Clavel F, Mammano F: Determination of coreceptor usage of human immunodeficiency virus type I from patient plasma samples by using a recombinant phenotypic assay. J Virol 200I, 75:25I-259.

67. Tajima F, Nei M: Estimation of evolutionary distance between nucleotide sequences. Mol Biol Evol I984, I:269-285.

Publish with Bio Med Central and every scientist can read your work free of charge

"BioMed Central will be the most significant development for disseminating the results of biomedical research in our lifetime. "

Sir Paul Nurse, Cancer Research UK

Your research papers will be:

- available free of charge to the entire biomedical community

- peer reviewed and published immediately upon acceptance

- cited in PubMed and archived on PubMed Central

- yours - you keep the copyright 